\title{
Publicly available information and the pricing of book built IPOs: Evidence from India
}

\author{
Neeta Jain ${ }^{1 *}$ and Anna Jain ${ }^{2}$ \\ ${ }^{1}$ Department of Management (Finance), NIMS University, Jaipur (Raj.), India. \\ ${ }^{2}$ Department of Management (Finance), Centum Learning Centre, Jaipur (Raj.), India. \\ Accepted January 12, 2011
}

\begin{abstract}
The pricing of initial public offering (IPO) plays a vital role for both the issuers and the investors. Therefore they also have a profound impact on the activities of primary and secondary capital markets. Extensive literature on pricing of IPOs has reported a significant mis-pricing across countries during different time periods. The present study analyzes the pricing of 207 book built IPOs listed on Bombay Stock Exchange (BSE) during the period from April 2004 to August 2009. The issuers provide rich information regarding their company and the issue pertaining to IPO before it gets listed. Therefore the study aims to find out how far the publicly available information about an IPO is affecting its pricing on the listing day. Furthermore the study identified the determinants of subscription pattern and opening returns on the listing day. It was found that different categories of investors do not subscribe independently. They instead look to the more informed investors to base their decisions. The results suggest that the issuers need to consider the impact of publicly available information before they decide the issue price.
\end{abstract}

Key words: IPO, Underpricing, overpricing, book building, subscription, market return, opening return.

\section{INTRODUCTION}

Financing is an imperative and major decision in any business organisation. The sources of finance thus become an important matter for any business. The sources of finance can be divided in two parts: Private sources and Public sources. Private sources are own wealth, earnings of the business, relatives, banks, financial institutions, etc. Public source is raising funds from the public. Going public is a very thoughtful decision for a company. Moreover, going public for the first time is an extraordinary event in any business. The first equity offering or issue by a company to the public is called initial public offering (IPO). On the event of IPO on the one side, the company reveals its value in the market and on the other side the market (investors) also decides the value of the company. Thus, determination of value of the company through determination of price of the IPO becomes a key aspect while going public. The international phenomenon is that valuation by the company differs from the valuation done by the market.

\footnotetext{
*Corresponding author. E-mail: jainneeta09@gmail.com.
}

The valuation differs because these two players have opposite interests. The issuing firm wants to raise maximum funds from the market by selling the issue at maximum price while investors want to buy at least price. Moreover the effect of pricing of the initial public offerings is not limited to these two parties. The pricing of initial public offerings affects economy also. As public offering is a way of resource mobilisation from investors to business projects that implies the resource mobilisation from low growth opportunities to high growth opportunities. Therefore if issuing firms keep very high offering price then it discourages investors for buying the issue while if it is very low then it discourages the issuing firms because leaving money in the market in terms of low offer price is an indirect cost of fund raising for the company. Here, low and high price is the deviation from the true value of the issue. The true value of the share is determined by the secondary market forces on the first trading day.

Public offerings can be categorised into two broad categories: Initial Public offerings (hereafter, IPO) and Follow on Public offerings (FPOs). The pricing of the issue has different implication for these two kinds of 
public offerings. In case of IPO, investors have very little information regarding such companies, while they have good amount of information of companies issuing FPO. Similarly, IPO firms find it difficult to gauge market's perception on their IPO. Therefore the present study aims to empirically analyse the pricing of book built initial public offerings in India.

There are different methods of IPO pricing namely: Fixed price method, Book Building method, and Auction method. These methods differ on account of freedom given to the market to decide the price at which IPO is to be sold. In the fixed price method the issuer only decides the price of the issue without any involvement of the market or investors. In the book building method price is partially decided by the issuer and partially decided by the investors. While in the auction method the price is fully determined by the market. Therefore, theoretically the difference between market price and the price determined by the issuer is maximum in fixed price method and it is least in auction method.

If the price determined by the issuer is less than the price determined by the investors then it is called underpricing. High Underpricing of IPOs is unhealthy for three players: The IPO issuing firm, the Capital Market and the Economy. The Company loses the amount of funds which could have been raised if it was not underpriced. Thus high underpricing is a high indirect cost of fund raising for the issuing firms. Moreover high underpricing leads oversubscription and thereby high refunding cost for the issuing firm. Underpricing creates arbitrage activities in the capital market. For an economy it reduces the resource mobilisation because those companies which do not want or cannot afford leaving money on the table would not raise funds by initial public offerings. Thus underpricing becomes a problem for any country.

Now what happens if an IPO is overpriced? If issue is overpriced then investors will not buy the shares because market value of the issue is less than what they pay for buying it from the issuer. Therefore to avoid initial losses investors will not subscribe to the issue and company will not be able to sell the issue. Moreover, in India minimum ninety percent subscription of the offer is mandatory for getting listed on the stock exchange. In case of less than ninety percent subscription firms shall take the offering back. Thus overpricing will make loss to the investors who have bought the overpriced shares and the company gets listed. On the other hand if the issuing firm is unable to get minimum subscription then it will not get listed on the stock exchange and it will face a huge cost of calling back the issue and will not get listed and cannot raise funds. Thus underpricing and overpricing of IPO both are harmful.

In India SEBI (Securities and Exchange Board of India) makes certain disclosures mandatory for the IPO issuing companies. According to SEBI guidelines IPO issuing companies need to disclose certain information in the offer document. Moreover in the process of book building investors get a lot of information about the IPO issuing company. Therefore the present study aims to find out how publicly available information affects pricing in the book building method. Till now no study has been carried out on the said objective of present study. Thus the study fills the research gap and brings a contribution to the body of literature and practitioners.

In the present study we examine the pricing of IPOs in Indian capital market for the book built equity IPOs issued and listed between March 2004 and August 2009.

\section{Review of literature on pricing of IPOs}

Loughran et al. (1994) studied IPOs of several countries and found that underpricing is an international phenomenon but the degree of underpricing differs from country to country because each country has different binding regulations, contractual mechanisms, and the characteristics of the firms going public. In the said study the latest data (updated November, 2008) on 39 countries shows that still these countries are facing a problem of high average initial return. The given data shows that China is having the maximum average under-pricing of $164.5 \%$ during $1990-2005$, in India it is $92.7 \%$ during 1990 to 2007 and in US it is $16.9 \%$ during $1960-2007$. Thus It has been found that the Initial Public Offerings are underpriced worldwide (Loughran et al., 1994). There are many theoretical explanations to underpricing as well as it has been a favourite topic of empirical research for academicians across the world.

The underpricing and overpricing are the results of the difference between the price set by the investors and price set by the issuer. Therefore question arises: Why companies do not opt for auction method only? Sherman (2005) carried out a thorough analysis on trends of IPO pricing method across countries. The author reported that during 1980s, book building was being used by North America only, but by the end of 1990s it was a dominant method in Europe, Asia and Latin America. Fixed price method is being abandoned worldwide and it is being used only in smaller countries where retail investors are dominant. Auctions are used only where book building method has some regulatory restriction. The author, in contradiction to the popular belief found that auctions always do not lead to lower expected underpricing and that the issuers prefer book building regardless of the change in underpricing levels. The auction method has advantage if the investors are scattered and well informed about the issuing firm and industry. Auctions are not preferred where investors have to put efforts to learn about a new issue. The author mentions that the issuer incurs the cost of information acquisition from the investors in case of both auction method as well as book building method. But both the methods are different in the sense that in book building issuer has greater control 
over information expenditures than in auction. Moreover auction has high probability of under subscription and thereby lower expected proceeds. Book building allows the underwriter to coordinate the informed and uninformed investors and thereby ensuring enough investors to participate in the offering. In Indian capital market this advantage has different implications as the subscription information is available at every half an hour. Thus uninformed investors can follow informed investors' subscription pattern. The author reported one more advantage of discretionary power of the issuing firm in share allocation, which is not available in Indian regulatory framework of book building in India.

India is not the only country which is facing problem of underpricing. As Su (2004) studied 283 IPOs in China between January 1994 and December 1997 and found maximum underpricing of $692.60 \%$, average underpricing of $129.36 \%$ and maximum overpricing of $36.64 \%$. Thus IPOs' pricing is highly deviated from the true value. Further he concluded that firms with higher pre-IPO leverage are more underpriced .Moreover timing of offering also found to be important in China, if issue comes when the market fluctuations are high and market return are low surrounding an IPO then underpricing is higher. Thus underpricing differs with firm's capital structure and market conditions during an IPO.

Sehgal and Singh (2007) studied 438 IPOs in India between June 1992 and March 2006 and found that average underpricing during the study period is $101 \%$, and maximum overpricing is $87.96 \%$. They found that underpricing is not good for investors also because in the studied IPOs there is no relationship between initial return and long term return. That indicates that investors cannot get any signal from the initial return of IPOs, on long term performance of IPOs.

Sahoo and Rajib (2009) studied 43 IPOs during 20012005 and found average undervaluation of $46.63 \%$ and standard deviation of initial returns is $78.65 \%$ implying high degree of variations in initial returns. They found that the issues which are managed or priced by prestigious investment banks are less underpriced compared to issues priced by less prestigious investment banks. Because the prestigious investment banks are managing issues with the help of large number of syndicate members than their non prestigious counterparts. The said study also found that investment banks manage issues with larger size, old firms and higher promoters' holding in the post issue equity capital. This implies that investors in India can have a presumption about the listing day price on the basis of type of investment bank for a specific issue. Thus in India issue characteristics contributed to the degree of underpricing.

Kohli (2009) studied 499 IPOs from April 1994 to March 2006 and found that stock markets in India suffered from the excessive optimism and poor valuation because he found that high prices of new issues are not related with their future profitability and growth in the sample. Pande and Vaidyanathan (2009) studied 55 book built IPOs listed between $26^{\text {th }}$ March 2004 to $31^{\text {st }}$ October 2006. Average underpricing in the sample was $22.62 \%$, maximum underpricing $82.50 \%$ and maximum overpricing was $33.40 \%$. They found that issues with offer price towards upper end of the offer price band are more underpriced as compared to issues which are priced towards the lower end of the offer price band and listing delay is positively related with underpricing.

A recent study on IPO underpricing by Deb (2009) found out the evidence of on average underpricing in India during 2001 to 2009 for a sample size of 187 IPOs. Moreover the author found that in the aftermarket short run investors are not getting any excess return on mispriced issues. It shows that underpricing does not bring consistent benefits to investors also.

Thus from the prior research it is obvious that IPO underpricing is higher for fixed price issues than for book built IPOs. However on the other hand researches on book built IPOs' pricing still indicate high underpricing or overpricing. Therefore still pricing of IPO is a matter of research to get it fairly priced.

\section{Regulatory framework for IPO pricing in Indian capital markets}

Before May 1992 as per the Capital Issue (Control) Act, 1947, the office of Controller of Capital Issue (CCl) had full control over the pricing of new issues in India. In May $1992 \mathrm{CCl}$ was abolished and Securities and Exchange Board of India (SEBI) was formed under the SEBI Act 1992. During the period 1992 to 1999 issuers were free to determine the issue price on the basis of own discretion. This method of free and fixed price suffered from high overpricing and underpricing because it was difficult for the issuer to decide appropriate price without any involvement of the market. Therefore book building method was introduced in October 1995 on the recommendation of an expert committee under the chairmanship of Mr. Y H Malegram appointed by SEBI. SEBI guidelines, 1995 define book-building as "a process undertaken by which a demand for the securities proposed to be issued by a body of corporate is elicited and built up and the price for such securities is assessed for the determination of the quantum of such securities to be issued by means of a notice, circular, advertisement, document or information memoranda or offer document". Thus book building is a process of determining price and gauging the market demand on the basis of bids received from the investors. The development of book building method in India has gone through many amendments in the guidelines. The first IPO through book building route was Hughes Software Systems Limited in September 1999. Though fixed price route is still available to the issuers, in the study period book built IPOs are more than fixed price issue. As Fixed price issues are around 25\% 
Table 1. Price discovery.

\begin{tabular}{cccc}
\hline $\begin{array}{c}\text { Bid } \\
\text { quantity }\end{array}$ & $\begin{array}{c}\text { Bid price } \\
\text { (Rs) }\end{array}$ & $\begin{array}{c}\text { Cumulative } \\
\text { quantity }\end{array}$ & $\begin{array}{c}\text { Subscription } \\
\text { (\%) }\end{array}$ \\
\hline 1000 & 40 & 1000 & 16.67 \\
1500 & 39 & 2500 & 50.00 \\
2000 & 38 & 4500 & 100.00 \\
2500 & 37 & 7000 & 166.67 \\
3000 & 36 & 10,000 & 250.00 \\
\hline
\end{tabular}

of the total IPOs in the study period. Thus in India book building method of IPO pricing dominates the fixed price method.

\section{Process of IPO pricing through book building}

In book building mechanism price determination has a long process. In India book building starts with a price band decided by the issuer in consultant with the Book Running Lead Manager (BRLM). As per the SEBI rule the price band's upper limit should not be more than $120 \%$ of lower limit of the band. For instance if lower band is Rs. 100 then upper band would not be more than Rs. 120.But the issuer has freedom of deciding the upper band between 100 and 120 in the given example. If issuer decides price below than Rs.120 then it is the underpricing in the first phase of pricing. Suppose issuer decides upper end of Rs. 110. Then maximum permissible upper end is Rs. 120 and maximum upper end actually used is Rs. 110. Then First underpricing is the percentage difference between these two upper ends. It is $[(120-110) / 120]^{\star} 100=8.33 \%$. After deciding the price band issuer opens price band to the investors to gauge the market demand on various prices within the band. The permitted period for subscription is 3 to 7 working days and extendable by 3 days in case of any price revision. On the basis of bids received during subscription period issuer decides the maximum of the received prices where the issue is fully sold.

\section{Illustration of book building and price discovery process}

Bidders can bid at any price within the given price band. For instance, suppose a price band of Rs. 36 to Rs. 40 per share, issue size of 4,500 equity shares and receipt of five bids from bidders, details of which are shown in the Table 1.

The price discovery is a function of demand at various prices. The highest price at which the issuer is able to sell the desired number of shares is the price at which the book cuts off, that is, Rs. 38 in the above example. The issuer, in consultation with the Book Running Lead manager. finalizes the issue price at or below such cut off price, that is, at or below Rs. 38 .

If this price decided on the basis of bids is less than the upper end of the price band actually used then it is underpricing in the second phase of pricing. The percentage difference between the actual upper end and the offer price is the underpricing. For instance, if actual upper end is 110 in the given example and the offer price is Rs. 105 then underpricing is $[(110-105) / 110]^{*} 100=4.54 \%$. The allocation of the issue is done within 15 days after closure of the issue. The bidding status during the subscription period is available on BSE/NSE websites on consolidated basis and on investors' category wise also.

The issued share gets listed on the exchange(s) within 3 weeks from the closure of the issue. The closing price on the listing day is considered as true value of the share because it is an equilibrium price in the open market .Therefore if on the listing day closing price is more than the maximum permissible upper end of the issue then it is called market underpricing of the share. If the closing price on the listing day is Rs. 125 then underpricing is $[(125-120) / 120]^{\star} 100=4.17 \%$. Thus first underpricing is done by the issuer while second pre-listing underpricing is partially controllable by the issuer because it depends on market demand/bids received from the investors and then a third type of underpricing is totally market determined excluding the underpricing done by the issuer. Now the total actual underpricing done by the issuer, investors and the market can be defined as [(125$105) / 105 * 100]=19.05 \%$.

The first attempt in bringing out the concept of three phases of underpricing of book built IPOs in India was by Khurshed et al. (2009). The present study aims to find out the impact of publicly available information on the pricing of book built IPOs.

The minimum allocation proportion of the issued shares into three categories of investors is regulated by the SEBI rule. The minimum $15 \%$ of net offer to public is to be allocated to retail investors, $35 \%$ to non institutional investors and $50 \%$ to qualified institutional investors. The allotment of shares to each category is done on the basis of these proportions.

\section{Publicly available information}

The following study variables are given in the sequence of availability of information to the investors:

1. Age of the firm: The period between incorporation date to listing date of the firm. Higher age shows long operating history of the firm therefore it gives good indication in the market. Therefore we assume that the investors give high value to an old firm's IPO than a young firm.

2. Issue Size: Issue size is defined as the number of shares offered through the offer document. The issue size 
indicates supply of the shares therefore if supply is high then the price in the secondary market on the listing day would remain lower and hence market underpricing should be less if issue size is large.

3. Promoters' Holding: It is defined as percentage of promoters' holding in the post issue equity of the company. As per the SEBI regulation $20 \%$ of the post issue equity is mandatory for the promoters. This $20 \%$ holding has lock-in period of 3 years and promoters' holding in excess of minimum promoters' contribution has lock-in period of one year. Leland and Pyle (1977) argued that promoters' holding indicates issuer's willingness to invest in the project and thereby information about the future profitability of the project. Therefore high promoters' holding conveys good quality of the project.

4. Pre-IPO Leverage: It is defined as proportion of total debt in the total asset before IPO. The latest data on leverage available in the offer document was taken. Ross (1977) argued that high leverage indicates high financial distress costs, Jensen and Meckling (1976) stated that high leverage causes high agency costs and Myers and Majluf (1984) developed a model of capital structure in which lower profitable firms go for high leverage because highly profitable firms have enough internal funds to finance. Thus as per the capital structure theories high leverage does not convey good signal in the market.

5. Index Return: It is defined as average daily return on Sensex 30 days before an IPO opening. It shows the market condition surrounding IPO. If index return is high then market is highly attractive for investors. Therefore being highly optimism in good market investors gives high value to the issue in terms of high price in the secondary market.

6. Index Volatility: It is standard deviation of daily returns on Sensex 30 trading days before an IPO opening. It is an indicator of uncertainty/fluctuations in the market surrounding a new IPO. If market is highly fluctuating then the IPO gets less value in the market.

7. Subscription: It is number of times issue subscribed. It is defined as number of shares applied for divided by number of shares offered. It indicates high demand of the issue therefore high price in the secondary market can be expected if an IPO is highly subscribed.

In India as per SEBI regulations investors of IPO are categorised into 3 categories. Qualified Institutional Buyers (QIBs), Non Institutional Investors (NIIs) and Retail Individual Investors (RIIs).QIBs are institutional investors, $\mathrm{NII}$ is an individual investing more than Rs. 100,000 in the issue and RII an individual who can invest up to Rs. 100,000. The allocation of issue to these categories is fixed by SEBI. As not more than $50 \%$ of net offer to the public shall be allocated for QIBs, not less than $15 \%$ of net offer to the public shall be allocated to NIIs and not less than $35 \%$ of net offer to the public shall be available for Rlls, as bigger investors are supposed to be more informed about the issue than smaller investors. Therefore it is possible that QIBs are more informed than
NIIs and RIls and NIls are more informed than RIls. Thereby NIls subscription may follow to subscription pattern of QIBs and RIls subscription pattern may follow to NIls subscription.

8. Listing delay: It is number of days between offer closing day and listing day. As the listing delay increases information dissemination about the IPO increases, therefore its impact on listing day price can be expected.

9. Opening return: It is defined as positive difference between opening price on the listing day and the offer price relative to offer price. This also can be used by the investors as signal of higher initial return and they become more optimistic about the issue till the closing on the listing day.

$\left[\left(\mathrm{OP}_{1}-\mathrm{OP}_{0}\right) / \mathrm{OP}_{0}{ }^{*} 100\right]$

$\mathrm{OP}_{1}=$ Opening price on listing day, $\mathrm{OP}_{0}=$ Offer Price

After adjusting it for market return between offer closing and listing day, the formula is:

Market Return $=\left[\left(\mathrm{OS}_{1}-\mathrm{OS}_{0}\right) / \mathrm{OS}_{0}{ }^{*} 100\right]$

Where, $\mathrm{OS}_{1}=$ Opening Sensex on the listing day, $\mathrm{OS}_{0}=$ Opening Sensex on the offer closing day.

Market Adjusted Opening return $(\mathrm{MAOP})=$ Opening Return - Market Return

\section{METHODOLOGY}

\section{Hypotheses}

As per the research objectives of the study, the null hypotheses which are being tested in the study are given below:

$\mathrm{H}_{1}$ : The publicly available information does not affect the pricing of IPOs.

$\mathrm{H}_{2}$ : All the three categories of investors are equally informed about the issue and hence subscribe independently.

These hypotheses will provide us with a certain way to achieve the objectives of the study.

\section{Materials and data}

This study consists sample size of 207 book built equity IPOs listed on Bombay Stock Exchange (BSE) between April 2004 to August 2009 (Table 2). The sample proportion in the population is around $94 \%$.

The data used in the study were collected from various authentic sources. The sources of data on IPOs which are available to the investors were taken for collecting the data for this study. The study aims to find out how far the publicly available information determines the degree of underpricing.

The source of data on price band, offer price, opening price on the listing day, closing price on the listing day, closing Sensex on the offer closing day and closing Sensex on the listing day, time delay between offer closing day and listing day is website of BSE, data on total assets, total loans, promoters' holding in the post issue equity, issue size, age of the firm were taken from the final offer documents filed with ROC/SEBI by the issuing firms available on website of Securities and Exchange Board of India (SEBI), data 
Table 2. Sample size of 207 book built equity IPOs listed on Bombay Stock Exchange (BSE) between April 2004 to August 2009

\begin{tabular}{lccc}
\hline Year (Financial year) & IPOs & $\begin{array}{c}\text { Amount } \\
\text { (Rs Crore) }\end{array}$ & $\begin{array}{c}\text { Book built } \\
\text { sample IPOs }\end{array}$ \\
\hline 2004 to 2005 & 23 & 13,749 & 13 \\
2005 to 2006 & 79 & 10,936 & 44 \\
2006 to 2007 & 77 & 28,504 & 64 \\
2007 to 2008 & 85 & 42,595 & 64 \\
2008 to 2009 & 21 & 2,082 & 18 \\
2009 to 2010 (April to Aug.) & 7 & 9,664 & \\
Total Book built IPOs & 292-72(fixed price issues) & & 207 \\
& $=220$ & & $(94.09 \%)$ \\
\hline
\end{tabular}

Source: SEBI Bulletin (September, 2009) and Website of BSE.

on subscription was collected from the Basis of Allotment documents available on web. Data on index return and index volatility before one month of IPO was taken from Prowess a CMIE database, though CMIE database is not available to all the investors but we assume that these data indicates market conditions surrounding IPO which is known to the investors.

\section{Formulae of the variables used in the study}

Thus underpricing in the above discussed book building process can be broken into the following categories:

First pre-Listing underpricing (Price band_UP)\% $=[($ MAXPMAXA)/MAXP*100]

Second pre-Listing underpricing (Offer Price_UP)\% $=[($ MAXAOP)/MAXA*100]

Where, $\mathrm{MXAP}=$ Maximum Permissible Price, MAXA =Maximum Actual Price and OP $=$ Offer Price.

Market underpricing (Market_UP) $\%=[$ CP-MAXP)/MAXP*100]

Where, MXAP = Maximum Permissible Price, MAXA $=$ Maximum Actual Price and $\mathrm{CP}=$ Closing Price

Adjusted Market_UP(\%) $=($ Market_UP $)-($ Market Return $)$

Or

$\left.[\mathrm{CP}-\mathrm{MAXP}) / \mathrm{MAXP}{ }^{*} 100\right]-\left[\left(\mathrm{CS}_{1}-\mathrm{CS}_{0}\right) / \mathrm{CS}_{0}\right]^{*} 100$

Where, $\mathrm{CS}_{1}=$ Closing Sensex on the listing day, $\mathrm{CS}_{0}=$ Closing Sensex on the offer closing day.

Initial Return $(\%)=\left[\left(\mathrm{CP}_{1}-\mathrm{OP}_{0}\right) / \mathrm{OP}_{0}\right]^{\star} 100$

Where, $\mathrm{CP}_{1}=$ closing price on the listing day and $\mathrm{OP}_{0}=$ offer price of the share

These returns after adjusting with the market returns are the market adjusted initial return as

Adjusted Initial Return= Initial Return - Market Return.

Market Return $(\%)=\left[\left(\mathrm{CS}_{1}-\mathrm{CS}_{0}\right) / \mathrm{CS}_{0}\right]^{*} 100$

Where, $\mathrm{CS}_{1}=$ Closing Sensex on the listing day, $\mathrm{CS}_{0}=$ closing
Sensex on the offer closing day.

Market Adjusted Opening Return (MAOR)\% $=\left[\left\{\mathrm{OP}_{1}-\mathrm{OP}_{0}\right) /\right.$ $\left.\left.\left.\mathrm{OP}_{0}\right\}^{*} 100\right]-\left[\left\{\mathrm{OS}_{1}-\mathrm{OS}_{0}\right) / \mathrm{OS}_{0}\right\}^{*} 100\right]$

Where, $\mathrm{OP}_{1}=$ listing price or opening price on the listing day, $\mathrm{OP}_{0}=$ offer price, $\mathrm{OS}_{1}=$ Opening Sensex on the listing day and $\mathrm{OS}_{0}=$ Opening Sensex on the offer closing day.

\section{Natural logarithm transformation of the variables}

To get the normality of the variables natural logarithm of the variables were taken. Normal curves before and after natural logarithm can be seen in the Histograms with normal curve in the Appendices (Figure 1A).

In Adjusted Market_UP $=\ln (\mathrm{CP} / \mathrm{MAXP})-\left(\mathrm{CS}_{1} / \mathrm{CS}_{0}\right)$

In Adjusted Initial Return $=\ln (\mathrm{CP} / \mathrm{OP})-\left(\mathrm{CS}_{1} / \mathrm{CS}_{0}\right)$

In MAOR $=\ln \left(\mathrm{OP}_{1} / \mathrm{OP}_{0}\right)-\left(\mathrm{OS}_{1} / \mathrm{OS}_{0}\right)$

In Issue Size

In Index Volatility

In Total Subscription

In QIBs, In NIIs, In RIIs

\section{Models used in the empirical analyses}

\section{Determinants of market underpricing}

In the model market underpricing adjusted for market return depends on the variables available at the time of listing day closing.

\section{Model 1(a)}

Ln Adjusted market _UP $=\beta_{0}+\beta_{1}$ Price band_UP $+\beta_{2}$ Offer price_UP $+\beta_{3}$ Age $+\bar{\beta}_{4}$ Listing delay $+\beta_{5}$ In Issue size $+\beta_{6}$ Index return $\bar{n}+\beta_{7}$ In Index volatility $+\beta_{8}$ Leverage $+\beta_{9}$ Promoters' holding $+\beta_{10} \ln$ Subscription .

\section{Model 1(b)}

Ln Adjusted market UP $=\beta_{0}+\beta_{1}$ Price band_UP $+\beta_{2}$ Offer price_UP $+\beta_{3}$ Age $+\bar{\beta}_{4}$ Listing delay $+\beta_{5}$ In Issue size $+\beta_{6}$ Index return $+\beta_{7}$ In Index volatility $+\beta_{8}$ Leverage $+\beta_{9}$ Promoters' holding $+\beta_{10}$ In MAOR. 
Table 3. Minimum, maximum, mean and standard deviation for sample of 207 book built IPOs in India during 2004 to 2009.

\begin{tabular}{lcccc}
\hline & Minimum & Maximum & Mean & Std. deviation \\
\hline Adjusted Total_UP (\%) & -36.60 & 334.93 & $\mathbf{2 8 . 1 7}$ & 49.74 \\
Price band_UP (\%) & 0.00 & 13.81 & 4.62 & 3.66 \\
Offer Price_UP (\%) & 0.00 & 16.67 & 2.17 & 4.47 \\
Adjusted Market_UP (\%) & -38.42 & 302.34 & 20.04 & 47.96 \\
QIBs (No. of times) & 0.02 & 252376.00 & 1247.17 & 17539.43 \\
NIIs (No. of times) & 0.05 & 306.63 & 33.77 & 50.14 \\
Rlls (No. of times) & 0.13 & 125929.00 & 647.96 & 8758.41 \\
Age (years) & 0.08 & 99.83 & 15.60 & 13.35 \\
Listing delay (Days) & 14.00 & 34.00 & 19.66 & 2.62 \\
Issue size (Lakh Shares) & 5.00 & 8658.30 & 266.06 & 818.84 \\
Total subscription (No. of times) & 0.91 & 145.57 & 22.98 & 28.24 \\
Index return (\%) & -20.15 & 23.72 & 2.96 & 7.36 \\
Index volatility (\%) & 0.29 & 16.79 & 2.42 & 2.67 \\
Leverage (\%) & 0.00 & 89.39 & 32.14 & 20.77 \\
Promoters Holding (\%) & 22.57 & 92.45 & 60.23 & 15.84 \\
Valid N (listwise) & 207.00 & & & \\
\hline
\end{tabular}

\section{Determinants of opening return on listing day}

\section{Model 2}

In the model market adjusted opening return depends on the variables available at the time of issue opening.

Ln Market adjusted opening return(MAOR) $=\beta_{0}+\beta_{1}$ Price band_UP $+\beta_{2}$ Offer price_UP $+\beta_{3}$ Age $+\beta_{4}$ Listing delay $+\beta_{5}$ In Issue size + $\beta_{6}$ In Subscription $+\beta_{7}$ Index return $+\beta_{8}$ In Index volatility $+\beta_{9}$ Leverage $+\beta_{10}$ Promoters' holding .

\section{Determinants of subscription pattern}

\section{Model 3(a)}

We regress QIBs subscription on the information available at the time of their subscription.

Ln Qualified Institutional Buyers(QIBs) $=\beta_{0}+\beta_{1}$ Price band_UP + $\beta_{2}$ Age $+\beta_{3}$ In Issue size $+\beta_{4}$ Index return $+\beta_{5}$ In Index volatility $+\beta_{6}$ Leverage $+\beta_{7}$ Promoters' holding .

\section{Model 3(b)}

In the model specification NIls subscription depends on the information available at the time of their subscription.

Ln Non Institutional Investors(NIIs) $=\beta_{0}+\beta_{1}$ Price band_UP $+\beta_{2}$ Age $+\beta_{3}$ In Issue size $+\beta_{4}$ Index return $+\beta_{5}$ In Index volatility $+\beta_{6}$ Leverage $+\beta_{7}$ Promoters' holding $+\beta_{8}$ In QIBs.

\section{Model 3(c)}

In the model specification RIls subscription depends on the information available at the time of their subscription.

Ln Retail Individual Investors(RIIs) $=\beta_{0}+\beta_{1}$ Price band_UP $+\beta_{2}$ Age $+\beta_{3}$ In Issue size $+\beta_{4}$ Index return $+\beta_{5}$ In Index volatility $+\beta_{6}$ Leverage $+\beta_{7}$ Promoters' holding $+\beta_{8} \ln$ QIBs $+\beta_{9} \ln$ NII.

\section{RESULTS AND ANALYSES}

This chapter covers data analysis and interpretations of empirical results.

\section{Descriptive statistics}

Table 3 shows the minimum, maximum, mean and standard deviation for the whole sample of 207 book built IPOs in India during 2004 to 2009 . The average adjusted initial return is $28.17 \%$ and maximum is $335 \%$ that implies that on average in India issuers left $28 \%$ of money which could have been raised if issues would have been priced at true value. Higher Standard deviation $49.74 \%$ indicates larger variance in underpricing, which can also be seen in the wide range of minimum and maximum. The minimum of adjusted initial return is 36.60 which shows overpricing of the issue that is, issuers could raise up to $37 \%$ in excess from the market than the true value of the issue. It discourages the investors to invest in IPOs.

In the sample 138 IPOs are underpriced and 69 IPOs are overpriced, which implies that either issuers left money on the table or investors faced the initial losses on their investments in IPOs. The total underpricing dissected into three categories as discussed in the section of book building process. By seeing maximum $14 \%$ price band_UP it can be concluded that on average underpricing is being done by the issuers also. In the sample 178 IPOs have positive price band_UP and only 29 issuers used MAXA=MAXP. Thus $86 \%$ of the issuers decided MAXA $<$ MAXP.

The maximum of offer price_UP shows that issuers 
Table 4. Regression analysis (Determinants of market underpricing).

\begin{tabular}{lcccccc}
\hline \multirow{2}{*}{ In Adjusted Market_UP } & \multicolumn{3}{c}{ Model 1 (a) } & \multicolumn{3}{c}{ Model 1(b) } \\
\cline { 2 - 8 } & B & p-value & VIF & B & p-value & VIF \\
\hline Constant & -0.05 & 0.781 & - & -0.027 & 0.884 & - \\
Price Band_UP (\%) & -0.01 & 0.234 & 1.25 & -0.007 & 0.22 & 1.25 \\
Offer Price_UP (\%) & -0.02 & $0^{*}$ & 1.32 & -0.021 & $0^{*}$ & 1.352 \\
Age (years) & 0.00 & 0.879 & 1.08 & 0.001 & 0.419 & 1.087 \\
Listing delay (Days) & 0.01 & 0.319 & 1.09 & 0.009 & 0.212 & 1.096 \\
In Issue size & -0.01 & 0.474 & 1.14 & -0.024 & 0.169 & 1.166 \\
Index return (\%) & 0.00 & 0.357 & 1.51 & -0.002 & 0.534 & 1.489 \\
In Index volatility & 0.01 & 0.618 & 1.44 & 0.011 & 0.656 & 1.44 \\
Leverage (\%) & 0.00 & 0.379 & 1.13 & -0.001 & 0.585 & 1.145 \\
Promoters holding (\%) & 0.00 & 0.334 & 1.13 & $6.90 \mathrm{E}-05$ & 0.956 & 1.129 \\
In subscription & 0.12 & $0^{*}$ & 1.33 & & & \\
In MAOR & - & - & - & 0.846 & 0 & 1.361 \\
& \multicolumn{7}{c}{} & & $\mathrm{R}^{2}=42 \%$ & & \\
& $\mathrm{R}^{2}=42.5 \%$ & $\mathrm{~F}=14.118(0.000)$ & \\
& $\mathrm{F}=14.490(0.000)$ & $\mathrm{df}=196$ & \\
\hline
\end{tabular}

*Significant at $1 \%$ level.

decided offer price below the MAXA up to 17\%. In the sample 187 IPOs 'offer price was set below to MAXA and only 20 IPOs' offer price was equal to MAXA.

It can be seen that maximum adjusted market_UP is $302.34 \%$ which is very high than the 14 and $17 \%$ of price band_UP and offer price_UP. In the sample 125 issues have positive adjusted market_UP and 82 issues having negative adjusted market _UP indicates that IPOs are either underpriced or overpriced in the market. But underpriced IPOs are more than overpriced IPOs. Average of adjusted market_UP also showing underpricing of around $20 \%$. Thus on average still problem of underpricing is more serious than overpricing. If we compare the subscription pattern of different investor categories then the mean subscription is highest for QIBS and it is minimum for Rlls. The other variables like age, issue size, subscription, leverage and promoters' holding are having a wide spread between minimum and maximum. It indicates a large variance between the issues or issues differ extensively on their characteristics. Therefore any analysis will be practical by considering these publicly available information also.

\section{Determinants of market underpricing}

In Appendix, Table 1A presents bivariate correlation among variables used in the model. It shows high correlation between opening return and subscription. To avoid the multi-collinearity problem in the model separate models for each of these two variables were taken.

In Table 4 models 1(a) and (b) aimed to find out the determinants of adjusted Market_UP. These models consider the information that is available to investors at the time of closing on the listing day. Model 1(a) considers total subscription with other variables excluding opening return while model 1 (b) considers opening return with other variables excluding total subscription. The multiple regression result of model $1(\mathrm{a})$ and (b) shows that adjusted opening return, offer price_UP and total subscription are significant variables of adjusted market underpricing. The negative sign of coefficient of offer price_UP indicates that market underpricing is high for those IPOs which have offer price close to upper end. This may be attributed to good quality perception by the investors if offer price is high and therefore theses IPOs are highly valued in secondary market on the listing day. The positive sign of subscription coefficient indicates that as total subscription increases market underpricing increases. The positive sign of opening return coefficient indicates that issues having higher return on opening are more underpriced in the market than IPOs having low opening return. Among the significant variables all three variables are not directly controllable. But if we can find out features of the firm/IPOs which are more having high return on opening, offer price closer to upper end and high total subscription then those findings may help in controlling market underpricing.

\section{Determinants of opening returns on listing day}

Table 5 shows that offer price UP, age and total subscription are significant determinants of opening return. Opening return is high for the IPOs with offer price close to upper end of the price band. Opening return is 
Table 5. Regression analysis (Determinants of opening returns on listing day): Model 2.

\begin{tabular}{lccc}
\hline $\begin{array}{l}\text { In Market Adjusted } \\
\text { Opening Return (MAOR) }\end{array}$ & B & $\begin{array}{c}\text { p- } \\
\text { value }\end{array}$ & VIF \\
\hline Constant & 0.093 & 0.339 & \\
Price Band_UP(\%) & 0.001 & 0.738 & 1.25 \\
Offer Price_UP(\%) & -0.007 & 0.005 & 1.32 \\
Age (years) & -0.001 & 0.074 & 1.08 \\
listing delay (Days) & -0.003 & 0.411 & 1.09 \\
In Issue size & 0.018 & 0.041 & 1.14 \\
In subscription & 0.081 & 0.000 & 1.33 \\
Index return (\%) & 0.001 & 0.516 & 1.52 \\
In Index volatility & -0.010 & 0.447 & 1.44 \\
Leverage (\%) & -0.001 & 0.099 & 1.13 \\
Promoters Holding (\%) & -0.001 & 0.088 & 1.13 \\
\hline
\end{tabular}

$R^{2}=53.2 \% ; R^{2}=53.2 \% ; F=22.287$ (0.000).

high for large issues than for smaller issues. It is high for the firms with high subscription because it indicates high demand of the issue. These three variables explain around $53 \%$ of the variance in opening return.

Thus subscription is a significant variable of opening returns also therefore now we go for analysing determinants of subscription for different categories of investors.

\section{Determinants of subscription}

In Appendix: Table A2 shows that subscription of three categories of investors is having different correlation (sign as well as degree) with other characteristics of the offerings therefore we expect different determinants of each category. As discussed QIBs are bigger investors than other two categories and NIls are bigger investors than RIIs.

\section{Determinants of QIBs' subscription}

Table 6 shows that subscription of QIBs significantly depends on index return, index volatility, leverage and promoters' holding. The positive sign of index return coefficient implies that QIBs subscribe more when market return surrounding IPO is high. The negative coefficient of index volatility implies that QIBs subscribe less if index returns are highly fluctuating surrounding IPO. The negative sign of leverage coefficient implies increase in QIBs subscription with any decreases in leverage. Similarly positive sign of promoters' holding coefficient indicates increase in QIBs' subscription with an increase in promoters' holding.

Thus firms with higher promoters holding, low leverage get more subscription from the QIBs than the firms with low promoters' holding and high leverage. Similarly issues in the time of high market return and less fluctuations in the market returns get high QIBs subscription.

\section{Determinants of NIls' subscription}

Table 7 shows that Nlls subscription depends on subscription of QIBs and promoters' holding. Surprisingly, in contrast to QIBs subscription, Nlls subscription is negatively related with promoters' holding. Interestingly, NIls subscription increases with an increase in QIBs' subscription because QIBs are more informed than NIIs, therefore they follow more informed investors.

\section{Determinants of Rlls' subscription}

In Appendix; Table A2 correlation matrix shows high correlation between NIIs and QIBs subscription, therefore stepwise regression can give a better model fit.

The result of stepwise regression in Table 8 shows that Rlls subscription depends on subscription of NIls, index return and issue size. As NIls subscription increases, Rlls subscription increases. And like QIBs, RIls also subscribes more when market return is high. For small issues Rlls subscribes more. This is possible because in small issues investors expect high initial return due to low supply. Independent Variables which are excluded due to low partial correlation with dependent variable (RIls) are given in (Appendix: Table A3).

\section{DISCUSSION}

1. Empirical results of the study show that when market return is high and less fluctuating then QIBs and Rlls subscription in an IPO increases and thereby results in high closing price on listing day. Therefore high market underpricing can be seen on any IPO if market conditions are good.

2. Pre-IPO leverage has negative impact on QIBs subscription. If it is high then QIBs subscription gets reduced and thereby market underpricing is lower in terms of lower closing price on listing day.

3. Promoters' holding has positive impact on QIBs' subscription and negative on NIls subscription. With promoters' holding QIBs subscription increases while NIls decreases.

4. Issue size has negative impact on RIls subscription but it has positive impact on opening return. Nlls follow to QIBs and RIls follow to Nlls subscription pattern. Therefore null hypothesis which says investors subscribe independently is rejected.

5. If offer price is close to upper end of the price band actually used (MAXA) then market under-pricing is high it implies that investors value high those firms which decide offer price close to upper end of the price band.

The finding of significant variables implies that the publicly 
Table 6. Determinants of QIBs' subscription: Model 3 (a).

\begin{tabular}{lccc}
\hline Dependent : In QIBs & B & p value & VIF \\
\hline Constant & 0.872 & 0.211 & \\
Price Band_UP (\%) & 0.030 & 0.405 & 1.179 \\
Age (years) & 0.005 & 0.559 & 1.041 \\
In Issue size & 0.139 & 0.215 & 1.133 \\
Index return (\%) & 0.056 & 0.004 & 1.355 \\
In Index volatility & -0.388 & 0.016 & 1.395 \\
Leverage (\%) & -0.013 & 0.044 & 1.086 \\
Promoters holding (\%) & 0.016 & 0.044 & 1.071 \\
\hline
\end{tabular}

$R^{2}=16 \% ; F=5.452(0.000) ; d f=199$.

Table 7. Determinants of NIls' subscription: Model 3 (b).

\begin{tabular}{lccc}
\hline Dependent : In NIIs & B & p value & VIF \\
\hline Constant & 1.45 & 0.012 & \\
In Price Band_UP & 0.030 & 0.308 & 1.18 \\
Age & -0.001 & 0.868 & 1.04 \\
In Issue size & 0.055 & 0.551 & 1.14 \\
Index return (\%) & 0.015 & 0.362 & 1.41 \\
In Index volatility & -0.100 & 0.450 & 1.44 \\
Leverage (\%) & -0.007 & 0.180 & 1.11 \\
Promoters holding (\%) & -0.016 & 0.014 & 1.09 \\
In QIB & 0.682 & 0.000 & 1.19 \\
\hline
\end{tabular}

$R^{2}=48.6 \% ; F=23.381(0.000) ; d f=198$.

Table 8. Stepwise Regression model: Model 3(c).

\begin{tabular}{|c|c|c|c|c|c|}
\hline \multicolumn{6}{|c|}{ Dependent variable :- In RIls } \\
\hline Model & & B & $p$ value & VIF & \\
\hline \multirow{2}{*}{1} & Constant & 0.39 & 0.001 & & \\
\hline & In NII & 0.63 & 0.000 & 1.00 & \\
\hline \multirow{3}{*}{2} & Constant & 0.36 & 0.002 & & \\
\hline & In NII & 0.59 & 0.000 & 1.07 & \\
\hline & Index return (\%) & 0.04 & 0.000 & 1.07 & \\
\hline \multirow{4}{*}{3} & Constant & 1.09 & 0.000 & & \\
\hline & In NII & 0.59 & 0.000 & 1.08 & \\
\hline & Index return (\%) & 0.04 & 0.000 & 1.07 & \\
\hline & In Issue size & -0.17 & 0.009 & 1.01 & \\
\hline Model & $\mathbf{R}^{2}$ & Adjusted $\mathbf{R}^{2}$ & df & $\mathbf{F}$ & Sig. \\
\hline 1 & 0.551 & 0.549 & 205 & 251.744 & $0.000^{a}$ \\
\hline 2 & 0.584 & 0.581 & 204 & 143.136 & $0.000^{b}$ \\
\hline 3 & 0.598 & 0.592 & 203 & 100.478 & $0.000^{c}$ \\
\hline
\end{tabular}

available information of an IPO affects its pricing. The information which has significant affect on pricing of an
IPO is promoters' holding, pre-IPO leverage, Subscription pattern of informed investors and size of the issue. Thus 
findings entail rejection of second null hypo-thesis which argues that publicly available information does not affect pricing of IPOs.

\section{Conclusion}

Initial public offerings are important source of corporate financing. It is used worldwide as a source of financing. The phenomenon of pricing and use of book building method is also not new and is widely used. However its application differs from country to country. Moreover in one market with the same method issues are priced differently. This kind of situation made us to search out the reasons of it. This study found that pricing in book built IPOs in India is inclined more towards underpricing. Book building has three phases of pricing in which it is found that on average issuers are also underpricing. But this study found that underpricing is high in the third phase of pricing where issue is priced in secondary market.

The empirical analysis found that publicly available information is making sense in Indian capital market. Therefore after disclose of the information its impact should also be considered. Issuers should decide the price with the prediction of impact of publicly available information. As underpricing harms to issuers and in long term to investors also while overpricing harms investors and in long term to issuers also when they come again in the market for follow on offerings. Therefore for win-win situation IPOs should be priced fairly.

The present study leaves immense scope for further studies which can be carried out by industry wise analysis, comparing with fixed price issues and searching some more important variables explaining market underpricing. It leaves the scope to find out why issuers decide price band below maximum permissible limit and the offer price below upper end of the price band actually decided. In the literature no study was carried out to find out the relevance of publicly available information and its impact on the pricing, thus present study bridges this research gap.

\section{REFERENCES}

Deb SG (2009). Some insights into IPO underpricing in India.Vilakshan 6(2):1-14.

Jensen MW, Meckling H (1976).Theory of the firm: Managerial behavior, agency costs and ownership structure. J. Financial Econ. 3(4):305-360.

Khurshed A, Pande A, Ajai KS (2009). A dissection of bookbuilt IPOs: Subscriptions, Undrepricing and Initial Returns. March, University of Manchester. Available at SSRN: http://ssrn.com/abstract=136191

Kohli V (2009). Do stock markets allocate resources efficiently? An examination of initial public offerings. Econ. Poll. Weekly 44(33):6372.

Leland HE, David HP (1977). Informational asymmetries, financial structure, and financial intermediation. J. Financial 32(2):371-387.

Loughran Tim, Jay RR, Kristian R (1994). . Initial public offerings: International insights. Pacific-Basin-Finance J. 2: 165-199. June
Myers SC, Nicholas SM (1984).Corporate financing and investment decisions when firms have information that investors do not have. J. Financial Econ. 13(2):187-221.

Pande A, Vaidyanathan R (2009). Determinants of IPO underpricing in the National Stock Exchange of India. ICFAI J. Appl. Financial 15(1):14-30.

Ross SA (1977). The determination of financial structure: The incentivesignalling approach. Bell J. Econ. 8(1):23-40.

Sahoo S, Prabina R (2009). Investment bank prestige and IPO underpticing: An empirical study. IIMB Mgt. Rev. 21(3):189-204.

Sehgal S, Balwinder S (2007). The Initial and Aftermarket Performance of Indian IPOs. ICFAI J. Appl. Financial 13(11):16-36.

Sherman AE (2005). Global trends in IPO method: Book building versus auctions with endogenous entry. J. Financial Econ. 78(3):615-649.

Su D (2004). Leverage, insider ownership, and the underpricing of IPOs in China. J. Int. Financial Markets, Institutions and Money 14(1):3754.

\section{Websites}

http://www.bseindia.com/

http://www.sebi.gov.in/

http://www.cmlinks.com/moneypore/ipo/ba.asp 


\section{APPENDICES}

Table 1A. Correlation analysis (a)

\begin{tabular}{|c|c|c|c|c|c|c|c|c|c|c|c|c|}
\hline & $\begin{array}{l}\text { In adjusted } \\
\text { Market_UP }\end{array}$ & $\begin{array}{c}\text { Price } \\
\text { band_UP (\%) }\end{array}$ & $\begin{array}{c}\text { Offer } \\
\text { price_UP (\%) }\end{array}$ & $\begin{array}{c}\text { Age } \\
\text { (years) }\end{array}$ & $\begin{array}{c}\text { listing } \\
\text { delay(Days) }\end{array}$ & $\begin{array}{l}\text { In Issue } \\
\text { size }\end{array}$ & $\begin{array}{c}\text { In } \\
\text { subscription }\end{array}$ & $\begin{array}{c}\text { Index return } \\
(\%)\end{array}$ & $\begin{array}{l}\text { In Index } \\
\text { volatility }\end{array}$ & $\begin{array}{c}\text { Leverage } \\
(\%)\end{array}$ & $\begin{array}{l}\text { Promoters } \\
\text { Holding (\%) }\end{array}$ & Ln MAOR \\
\hline In adjusted Market_UP & 1 & 0.034 & $-0.471\left(^{* *}\right)$ & 0.065 & 0.078 & -0.020 & $\left.0.5799^{* *}\right)$ & $0.161\left(^{*}\right)$ & -0.113 & $-0.173\left(^{*}\right)$ & -0.080 & $0.582\left(^{* *}\right)$ \\
\hline Price band_UP(\%) & & 1 & $-0.177\left(^{*}\right)$ & -0.077 & 0.046 & $-0.261\left(^{* *}\right)$ & 0.023 & $-0.174\left(^{*}\right)$ & $-0.247\left(^{* *}\right)$ & $\left.-0.206^{* *}\right)$ & 0.025 & -0.0035 \\
\hline Offer price_UP(\%) & & 1 & & -0.131 & -0.051 & 0.023 & $-0.397\left(^{* *}\right)$ & $\left.-0.238^{(* *}\right)$ & $-0.146\left(^{*}\right)$ & $0.167\left(^{*}\right)$ & 0.077 & $\left.-0.4211^{* *}\right)$ \\
\hline Age(years) & & 1 & & & 0.101 & $0.151^{*}$ & 0.092 & 0.083 & 0.014 & 0.017 & 0.120 & -0.0011 \\
\hline Listing delay(Days) & & & 1 & & & 0.004 & 0.002 & 0.107 & 0.035 & -0.095 & $\left.-0.185^{(* *}\right)$ & -0.014 \\
\hline In Issue Size & & & 1 & & & & .068 & 0.049 & -0.089 & $0.157\left(^{*}\right)$ & $0.168\left(^{*}\right)$ & 0.103 \\
\hline In Subscription & & & & 1 & & & & $0.323\left(^{* *}\right)$ & $-0.262\left({ }^{* *}\right)$ & -0.121 & 0.059 & $0.688\left(^{* *}\right)$ \\
\hline Index Return (\%) & & & & & 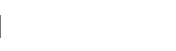 & & & & $\left.-0.506^{(* *}\right)$ & 0.075 & 0.027 & $\left.0.273^{(* *}\right)$ \\
\hline In Index Volatility & & & & & 1 & & & & & -0.101 & -0.021 & $-0.235\left(^{* *}\right)$ \\
\hline Leverage (\%) & & & & & 1 & & & & & & $0.159\left(^{*}\right)$ & $-0.176\left(^{*}\right)$ \\
\hline Promoters Holding (\%) & & & & & & & & & & & 1 & -0.063 \\
\hline Ln MAOR & & & & & & .. & & & & & & 1 \\
\hline
\end{tabular}

** Correlation is significant at the 0.01 level (2-tailed); ${ }^{*}$ Correlation is significant at the 0.05 level (2-tailed); a List wise $\mathrm{N}=207$.

Table A2. Regression analysis (Determinants of QIBs' subscription).

\begin{tabular}{|c|c|c|c|c|c|c|c|c|c|c|}
\hline & $\begin{array}{c}\text { Price band_UP } \\
(\%)\end{array}$ & Age & $\begin{array}{l}\text { In Issue } \\
\text { size }\end{array}$ & $\begin{array}{c}\text { Index } \\
\text { return (\%) }\end{array}$ & $\begin{array}{l}\text { In Index } \\
\text { volatility }\end{array}$ & $\begin{array}{c}\text { Leverage } \\
(\%)\end{array}$ & $\begin{array}{l}\text { Promoters } \\
\text { Holding (\%) }\end{array}$ & In QIB & In NII & In RIIs \\
\hline Price band_UP (\%) & 1 & -0.077 & $-0.261\left({ }^{* *}\right)$ & $-0.174\left(^{*}\right)$ & $0.244\left({ }^{* *}\right)$ & $-0.206\left(^{* *}\right)$ & 0.025 & -0.019 & 0.027 & 0.027 \\
\hline Age & 1 & & $0.151\left(^{\star}\right)$ & 0.083 & -0.060 & 0.017 & 0.120 & 0.091 & 0.042 & 0.030 \\
\hline In Issue Size & & 1 & & .049 & -0.089 & $0.157\left(^{*}\right)$ & $0.168\left(^{\star}\right)$ & 0.105 & 0.059 & -0.067 \\
\hline Index Return (\%) & & 1 & & & $-.506\left({ }^{* \star}\right)$ & 0.075 & 0.027 & $0.304\left({ }^{* *}\right)$ & $0.260(* *)$ & $0.368\left(^{* *}\right)$ \\
\hline In Index volatility & & & 1 & & & -0.101 & -0.021 & $-0.282\left({ }^{* *}\right)$ & $-0.237\left({ }^{* \star}\right)$ & $--0.318(* *)$ \\
\hline Leverage (\%) & & & 1 & & & & $0.159\left(^{*}\right)$ & -0.078 & $-0.142\left(^{\star}\right)$ & -0.068 \\
\hline Promoters Holding (\%) & & & & 1 & & & & $0.145\left(^{*}\right)$ & -0.040 & -0.104 \\
\hline In QIB & & & & & & & & & $0.674\left({ }^{* *}\right)$ & $0.557\left(^{\star \star}\right)$ \\
\hline In NII & & & & & 1 & & & & & $0.742\left(^{\star \star}\right)$ \\
\hline In RIls & & & & & & 1 & & & & \\
\hline
\end{tabular}


Table A3. Excluded variables.

\begin{tabular}{|c|c|c|c|c|c|c|c|c|}
\hline \multirow{2}{*}{ Model } & & \multirow{2}{*}{ Beta In } & \multirow{2}{*}{$\mathbf{t}$} & \multirow{2}{*}{ Sig. } & \multirow{2}{*}{$\begin{array}{c}\text { Partial } \\
\text { correlation }\end{array}$} & \multicolumn{3}{|c|}{ Collinearity statistics } \\
\hline & & & & & & Tolerance & VIF & Minimum tolerance \\
\hline \multirow{8}{*}{1} & Price band_UP (\%) & $0.007(\mathrm{a})$ & 0.144 & 0.886 & 0.010 & 0.999 & 1.001 & 0.999 \\
\hline & Age (years) & $-0.001(a)$ & -0.016 & 0.987 & -0.001 & 0.998 & 1.002 & 0.998 \\
\hline & In Issue size & $-0.111(a)$ & -2.388 & 0.018 & -0.165 & 0.997 & 1.003 & 0.997 \\
\hline & Index return (\%) & $0.187(\mathrm{a})$ & 4.006 & 0.000 & 0.270 & 0.932 & 1.073 & 0.932 \\
\hline & In Index volatility & $-0.150(a)$ & -3.183 & 0.002 & -0.218 & 0.944 & 1.060 & 0.944 \\
\hline & Leverage (\%) & $0.038(a)$ & 0.806 & 0.421 & 0.056 & 0.980 & 1.021 & 0.980 \\
\hline & Promoters Holding (\%) & $-0.074(a)$ & -1.588 & 0.114 & -0.110 & 0.998 & 1.002 & 0.998 \\
\hline & In QIB & $0.103(a)$ & 1.640 & 0.103 & 0.114 & 0.546 & 1.831 & 0.546 \\
\hline \multirow{7}{*}{2} & Price Band_UP (\%) & $0.042(b)$ & 0.916 & 0.361 & 0.064 & 0.964 & 1.037 & 0.900 \\
\hline & Age(years) & $-0.014(b)$ & -0.318 & 0.751 & -0.022 & 0.993 & 1.007 & 0.927 \\
\hline & In Issue size & $-0.117(b)$ & -2.626 & 0.009 & -0.181 & 0.995 & 1.005 & 0.930 \\
\hline & In Index volatility & $-0.080(b)$ & -1.513 & 0.132 & -0.106 & 0.732 & 1.367 & 0.723 \\
\hline & Leverage (\%) & $0.017(b)$ & 0.367 & 0.714 & 0.026 & 0.966 & 1.035 & 0.906 \\
\hline & Promoters holding (\%) & $-0.081(b)$ & -1.806 & 0.072 & -0.126 & 0.997 & 1.003 & 0.930 \\
\hline & In QIB & $0.061(b)$ & 0.985 & 0.326 & 0.069 & 0.528 & 1.893 & 0.528 \\
\hline \multirow{6}{*}{3} & Price band_UP (\%) & $0.012(c)$ & 0.254 & 0.800 & 0.018 & 0.899 & 1.113 & 0.899 \\
\hline & Age(years) & $0.003(c)$ & 0.062 & 0.951 & 0.004 & 0.971 & 1.030 & 0.926 \\
\hline & In Index volatility & $-0.090(c)$ & -1.725 & 0.086 & -0.120 & 0.728 & 1.373 & 0.723 \\
\hline & Leverage (\%) & $0.037(\mathrm{c})$ & 0.815 & 0.416 & 0.057 & 0.940 & 1.064 & 0.901 \\
\hline & Promoters holding (\%) & $-0.063(c)$ & -1.399 & 0.163 & -0.098 & 0.968 & 1.033 & 0.927 \\
\hline & In QIB & $0.075(c)$ & 1.226 & 0.222 & 0.086 & 0.525 & 1.906 & .525 \\
\hline
\end{tabular}

Predictors in the Model: (Constant), In NII; Predictors in the model: (Constant), In NII, Index return (\%), Predictors in the model: (Constant), In NII, Index return (\%), In Issue size; Dependent variable: In RIls. 

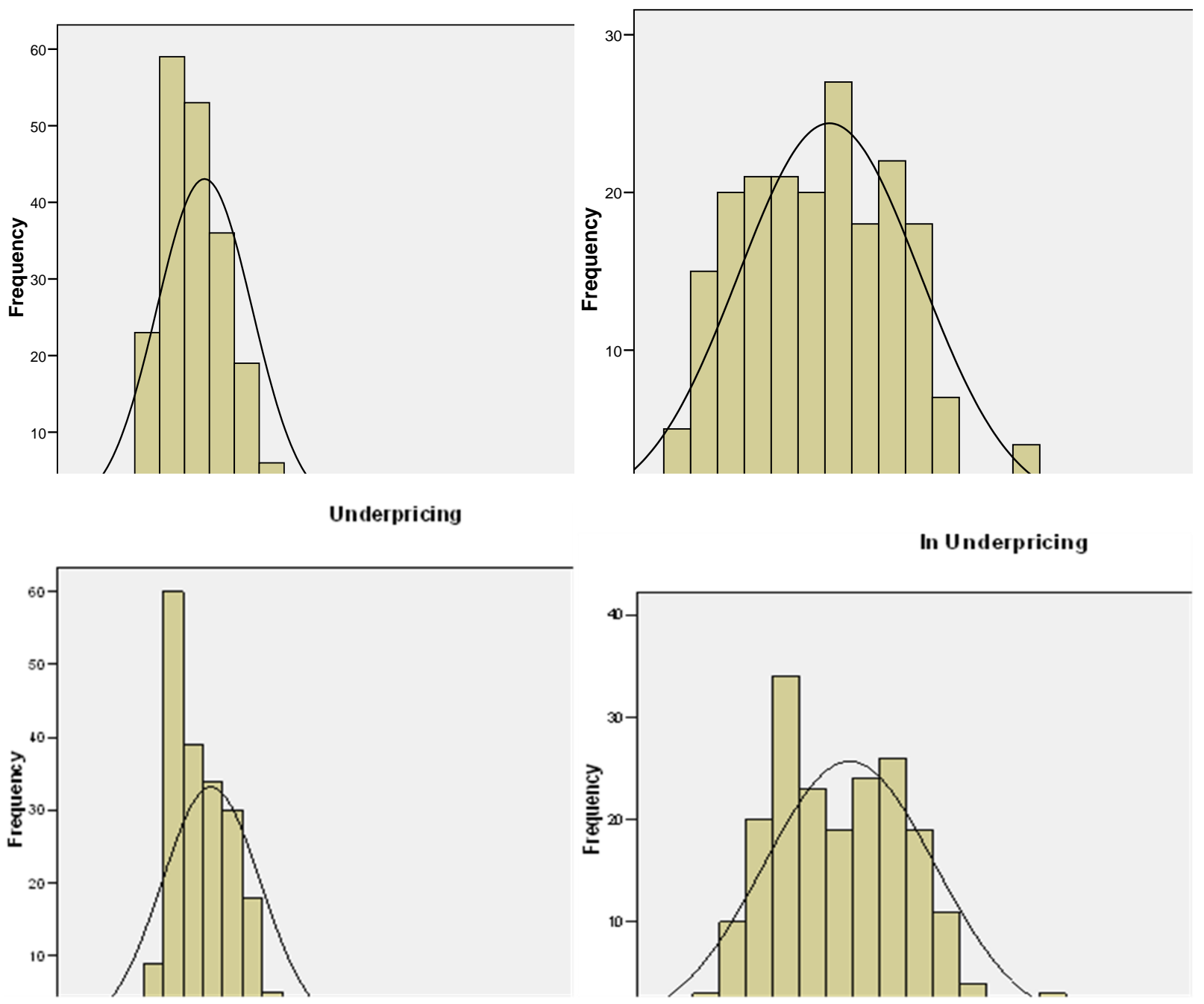

Qualified Institutional Buyers
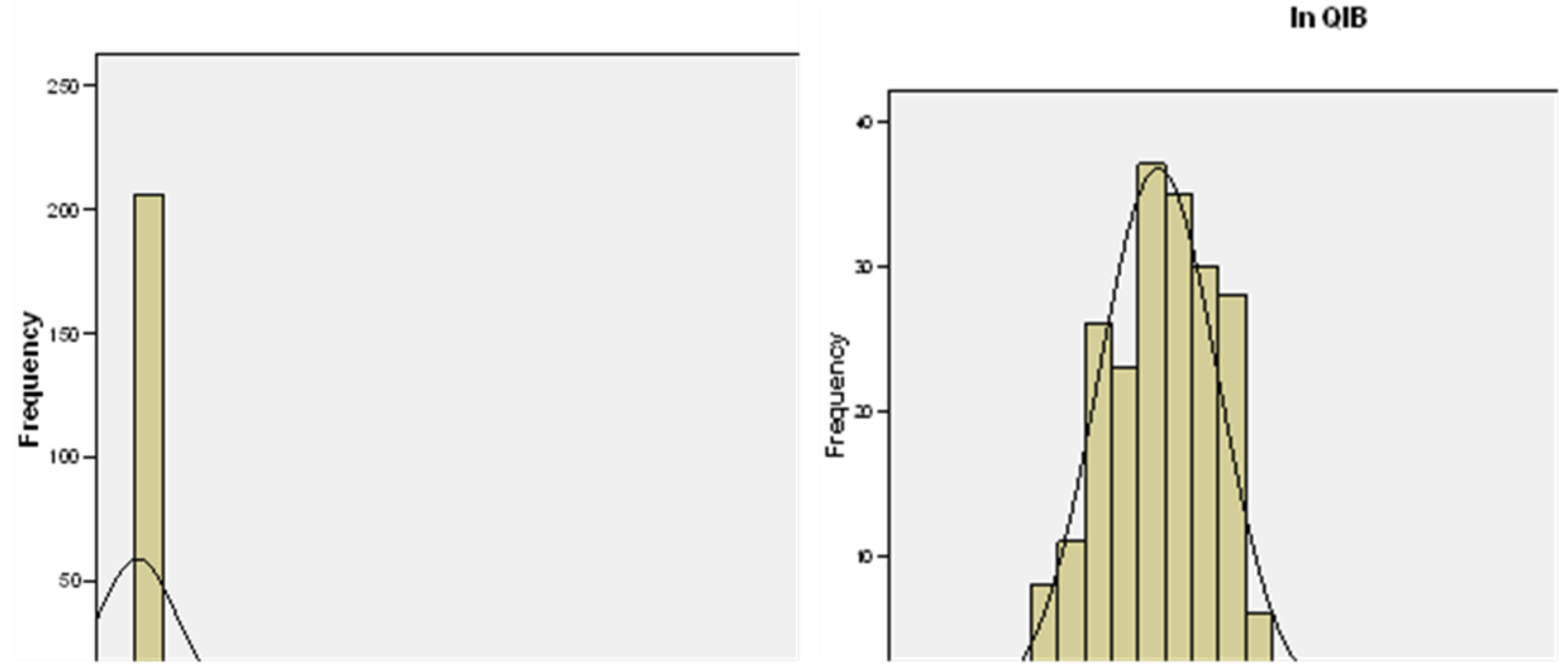

Figure 1A. Histograms with normal curve. 


\section{Qualified Institutional Buyers}
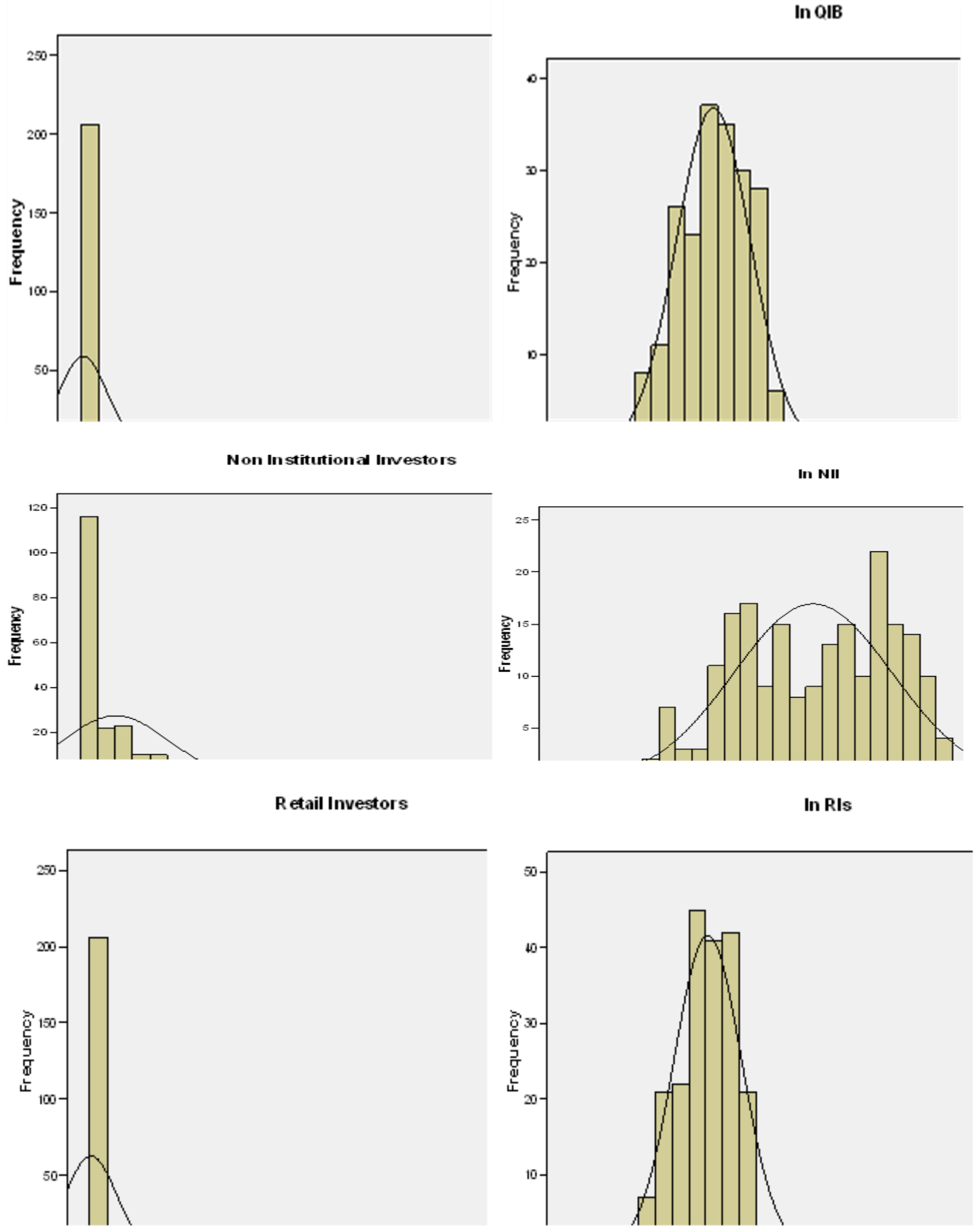

Figure 1A. Contd. 



Figure 1A. Contd. 